\title{
REFLEKSI DALAM MEMAKNAI EKSISTENSI RAKYAT; ANTARA PEMILIHAN PRESIDEN DAN PEMILIHAN MPR
}

\author{
Efriza \\ Sekolah Tinggi Ilmu Pemerintahan Abdi Negara (STIP-AN), Jakarta \\ email :efriza.riza@gmail.com
}

Paper Accepted: 15 Maret 2018 Paper Reviewed: 20-27 Maret 2018 Paper Edited: 01-15 April 2018 Paper Approved: 20 April 2018

\begin{abstract}
This paper attempts to re-unravel the results of the 1945 amendment in analyzing the development and division in Indonesia, highlighting democracy and the people between the President's choice directly with the President's choice through the MPR, and addressing the 1945 Constitution amendment as the basis of the spirit of constitutional democracy in Indonesia. The results of this study clearly explain that democracy in Indonesia is more favorable based on the results of the 1945 Amendment and the Presidential Election directly and better and as part of the implementation of constitutional democracy in a more comprehensive manner.
\end{abstract}

Keywords: Voters, Political Parties, Presidential Election, MPR and Constitutional Democracy

\section{PENDAHULUAN}

Demokrasi dalam realitas cenderung dianggap menghasilkan orang-orang bodoh ke tampuk kekuasaan dan kian dramatis bahwa dianggap keterpilihan orang-orang bodoh itu disebabkan oleh "pemilih yang bodoh." Argumentasi ini juga disertai oleh masukan atau dorongan bahwa lebih baik pemilihan umum dikembalikan ke sistem tidak langsung yakni dipilih oleh Majelis Permusyawaratan Rakyat (MPR).

Perdebatan yang memunculkan argumentasi di atas, akhirnya menyembulkan pertanyaan, apakah sistem pemilihan umum langsung memang tidak lebih baik daripada sistem pemilihan yang lalu melalui MPR? Sayangnya perdebatan atas pertanyaan di atas, kerap mengabaikan posisi partai politik itu sendiri, perdebatan tersebut hanya terhadap dua arus semata pemilihan langsung atau pemilihan tidak langsung melalui MPR. Perdebatan itu akhirnya hanya bermuara bahwa pemilihan umum adalah ekspresi kehendak rakyat, tetapi apa yang tergambarkan dari hasil pilihan rakyat tersebut tidak teruraikan secara jelas.
Padahal jika coba diuraikan perdebatan tersebut secara lebih komprehensif maka yang turut pula bertanggung jawab akan fenomena "orang-orang bodoh" ke tampuk kekuasaan adalah partai politik itu sendiri. Di era Reformasi ini telah sangat tegas diatur dalam konstitusi bahwa untuk mencalonkan diri sebagai anggota DPR, sebagai calon Presiden dan Wakil Presiden dipilih melalui partai politik, semangat ini seperti mengagungkan apa yang dikatakan oleh EE Schattschneider (1942) pada pertengahan abad ke-20, bahwa "partai politik menciptakan demokrasi, dan demokrasi modern tak terpikirkan tanpa partai," (Richard S. Katz dan William Crotty, 2014: 22). Telah jelas bahwa institusi pengusung calon-calon pengisi jabatan publik adalah melalui partai politik. Artinya, partai politik merupakan media yang bertanggung jawab bagi hadirnya pejabat publik yang "kontroversial" sehingga dianggap "orang-orang bodoh" ke tampuk kekuasaan, dan akhirnya kita akan secara jelas dapat merefleksikan sistem pemilihan umum sekaligus perkembangan partai politik di Indonesia dalam era Reformasi ini. 


\section{METODE PENELITIAN}

Penelitian ini dirancang menggunakan pendekatan kualitatif dengan teknik pengumpulan data terdiri atas hasil wawancara mendalam (in-depth interview) sebagai data primer dan studi pustaka merupakan data sekunder. Wawancara dilakukan berdasarkan pedoman wawancara dan beberapa pertanyaan terbuka. Wawancara dilakukan secara mendalam yang dikategorikan pada dua kelompok: (1). Pelaku/Akademisi yang turut terlibat dalam proses Amandemen UUD 1945 (tahun 1999-2002); dan (2) Peneliti/Akademisi yang meneliti dan menyoroti lembaga parlemen Indonesia. Setelah teknik pengumpulan data dilakukan maka data tersebut akan diolah, dianalisis dan dilakukan interpretasi data, sehingga akan menghasilkan suatu temuan atau hasil penelitian yang akan menjawab pertanyaan penelitian yang diajukan, (Haris Herdiansyah, 2010; Sanipah Faisal, 2008).

\section{HASIL DAN PEMBAHASAN}

Perubahan UUD 1945 kian mengukuhkan Indonesia telah menyempurnakan bangunan demokrasi konstitusionalnya. Dari sisi pemahaman kedaulatan rakyat, kekuasaan tertinggi dalam suatu negara berada di tangan rakyat dan dilaksanakan menurut UndangUndang Dasar. Kedaulatan rakyat menunjukkan bahwa rakyatlah yang pada hakikatnya memiliki kekuasaan tertinggi dalam suatu negara. Pemerintahan dalam suatu negara dilakukan dari, oleh, dan untuk rakyat.

Namun demikian, dalam pelaksanaan demokrasi pemerintahan tidak mungkin benarbenar dilaksanakan oleh rakyat, sehingga muncullah praktik demokrasi perwakilan. Rakyat terlibat secara langsung hanya dalam bentuk pemilihan umum untuk memilih wakilwakilnya di lembaga perwakilan rakyat. Di samping itu, bercermin secara konsep, Indonesia telah menentukan pilihannya menerapkan sistem presidensial, ini artinya bahwa pemegang kekuasaan pemerintahan adalah presiden, yang terpisah dengan kelembagaan parlemen. Pemisahan itu tentu saja harus diperkuat dengan legitimasi politik yang sama antara presiden dan parlemen, yaitu sama-sama dipilih oleh rakyat, dan juga diupayakan memberikan legitimasi yang kuat bagi Presiden dengan cara Presiden dipilih secara terpisah dari anggota-anggota DPR. Sehingga demikian, dalam jabatan presiden maupun parlemen juga terdapat unsur mewakili rakyat, terutama untuk menjalankan pemerintahan, (Janedjri M. Gaffar, 2012: 5 dan 121; dan Wawancara, Maswadi Rauf, 2015).
Hal di atas adalah beberapa pokok sistem pemerintahan di Indonesia dan dasar-dasar lainnya, uraiannya sebagai berikut.

\section{Memaknai Perubahan Demokrasi di Indonesia}

Jika membahas kembali ke kondisi awal bahwa pembentukan Majelis Permusyawaratan Rakyat (MPR) dalam UUD 1945 asli, memang tidak dirinci secara tegas. Yang mendasari adanya lembaga MPR ini ditenggarai keinginan bangsa Indonesia sejak kemerdekaan untuk mendirikan sebuah negara demokrasi, yakni melibatkan seluruh rakyat dalam seluruh proses dan kehidupan berbangsa, bernegara, dan bermasyarakat. Pelibatan seluruh rakyat itu dilembagakan dalam sebuah institusi atau lembaga negara yang bernama MPR. Pembentukan MPR ini dimaksudkan untuk mewakili atau sebagai penjelmaan dari seluruh rakyat dalam mengejawantahkan pelaksanaan kedaulatan rakyat, (Indra J. Piliang dan T.A. Legowo, 2006; dan Formappi, 2005).

Ketentuan yang menegaskan itu adalah UUD 1945 (sebelum perubahan) dalam Pasal 1 ayat (2) menyatakan bahwa "Kedaulatan adalah di tangan rakyat, dan dilakukan sepenuhnya oleh MPR." Secara normatif dan praktik ternyata Indonesia menerapkan perpaduan antara sistem presidensial dan parlementer yang disebut sistem kekeluargaan (Nurliah Nurdin, 2012: 54). Konsekuensinya, kepenuhan sebagai pelaksana kedaulatan rakyat menjadikan MPR sebagai lembaga yang dapat berbuat apapun (omnipotent) atau berada di atas semua lembaga yang lain (supremacy). Gagasan dari institusi MPR ini sebetulnya merupakan bentuk dari supremasi parlemen (parliamentary supremacy), dengan tiga ciri yang menonjol bahwa pertama, negara tersebut memiliki sebuah organ atau lembaga negara tertinggi dan memiliki kekuasaan tidak terbatas sehingga tidak ada suatu lembaga negara lain yang dapat menandingi; kedua, lembaga tersebut menjalankan fungsi parlemen; dan ketiga segala keputusannya tidak dapat dibatalkan atau diubah oleh lembaga negara yang lain. Namun uniknya, MPR merupakan perpaduan dari gagasan sistem presidensial dan parlementer yang hanya ada di Indonesia, dikatakan tidak lazim, sebab supremasi parlemen selalu bergandengan dengan sistem pemerintahan parlementer bukan presidensial seperti di Indonesia, (Efriza dan Yoyoh Rohaniah: 2016; Wawancara I Made Leo Wiratma, 2015).

Perkembangan selanjutnya, dalam rangka pemurnian sistem presidensial adalah memperbaharui (eksistensi) MPR, sehingga 
kedudukan MPR tidak lagi sebagai lembaga tertinggi negara melainkan tidak lebih dari lembaga tinggi negara biasa (sejajar) sekaligus MPR tidak lagi sebagai lembaga penjawantahan pelaksana kedaulatan rakyat karena ditinggalkannya prinsip supremasi parlemen diganti dengan penerapan supremasi konstitusi. Di samping itu, amandemen UUD 1945 tersebut telah menunjukkan Indonesia ingin benar-benar berkembang dan memastikan berjalannya prinsip demokrasi konstitusional (constitutional democracy) yang bergerak dinamis dari waktu ke waktu dengan tujuan menghapus kekuasaan absolut hingga konstitusi menjadi kuasa tertinggi dalam negara. Tidak hanya itu, konstitusi pun memberikan desain bagaimana hubungan di antara lembaga-lembaga negara. Tujuannya jelas, tidak boleh ada penumpukan kekuasaan pada satu lembaga negara saja, (Janedjri M. Gaffar, 2012: xiii).

Agar kelemahan tersebut tidak terulang lagi, dalam reformasi konstitusi (1999-2002), MPR berupaya melakukan desain ulang hubungan antar-lembaga negara. Desain baru yang dihasilkan tidak ada lagi lembaga negara sebagai pemegang kedaulatan rakyat secara tunggal, UUD 1945 hasil perubahan secara eksplisit menyatakan bahwa kedaulatan berada di tangan rakyat dan dilaksanakan menurut Undang-Undang Dasar, (Pasal 1 ayat (2)). Berdasarkan ketentuan itu maka tidak ada lagi sebutan lembaga tertinggi dan lembaga tinggi negara, yang ada merupakan bentuk sejajar antar lembaga negara. Amandemen UUD 1945 juga menganut paham supremasi konstitusi bukan supremasi parlemen, sehingga otomatis bahwa tidak adanya pembagian kekuasaan yang bersifat horizontal (dengan division of power) melainkan yang bersifat vertikal (dengan separation of power dan bersamaan terwujudnya hubungan checks and balances). Di samping itu, kekuasaan Presiden juga dibatasi hingga tidak mungkin lagi dengan kekuasaan terpusat sebagaimana pengalaman zaman Orde Lama dan Orde Baru. Kewenangan membentuk undang-undang yang berada di DPR dan Presiden terbuka untuk dikoreksi melalui proses judicial review kepada Mahkamah Konstitusi (MK). Hasil perubahan UUD 1945, secara prinsip disemangati dan berupaya membangun demokrasi konstitusional dalam pemaknaan yang sesungguhnya dan menguatkan sistem presidensial di Indonesia, (Janedjri M. Gaffar, 2012: xvi-xvii).

\section{Rakyat Memilih Presiden dalam Pemilihan Presiden secara Langsung}

Para penyusun UUD berusaha menyusun sistem pemerintahan sendiri dikenal dengan sistem kekeluargaan, yang disusun berdasarkan variasi antara memadukan kekuatan sistem presidensial di Amerika Serikat dan Sistem Parlementer di Inggris yakni, mengadopsi sistem Amerika tentang fixed government, dan mengadopsi sistem di Inggris yang memunyai lembaga tertinggi yang 'supreme' tempat kedaulatan rakyat (locus of sovereignty) berada, (RM. A.B. Kusuma, 2004: 38).

Sistem itu ialah Kepala Negara tidak bertanggung jawab kepada Badan Perwakilan Rakyat, tetapi ia bertanggung jawab sepenuhpenuhnya kepada MPR yang tiap-tiap lima tahun bersidang, dan pada waktu itu sudah tentu akan terang apakah haluan yang dijalankan oleh pemerintah disetujui atau tidak oleh MPR. Menteri-menteri hanya tunduk kepada Kepala Negara, (RM. A.B. Kusuma, 2005: 123; dan Saafroedin Bahar, Ananda B. Kusuma, dan Nannie Hudawati, 1995: 304). Sistem ini oleh Soepomo disebut sebagai sistem kekeluargaan, hal mana kepala negara diberikan konsentrasi kekuasaan dan tanggung jawab yang lebih dominan, (Nurliah Nurdin, 2012: 5).

Untuk menghindari kekuasaan kepala negara yang tanpa batas yang dapat mengarah pada totaliarisme, Muhammad Yamin mengajukan suprastruktur politik ke dalam enam lembaga negara yaitu kekuasaan Presiden, DPR, MPR, BPK, MA dan DPA. Sementara itu, Soepomo tidak seluruhnya menolak argumen Muhammad Yamin tersebut, namun mengajukan suatu institusi perwakilan yang memiliki kekuasaan tertinggi untuk memilih seorang kepala negara. Kepala negara yang ditunjuk oleh sebuah institusi yang diberi nama MPR. MPR ini mengidentifikasi dengan pengetahuan yang dimiliki untuk memilih kepala negara yang dianggap mampu membawa bangsa menyelesaikan urusan pemerintahan. MPR melakukan kontrol terhadap kepala negara dan melakukan pemilihan setiap lima tahun sekali. Hampir semua aggota Panitia Persiapan Kemerdekaan Indonesia (PPKI) yang hadir dalam pertemuan menyetujui ide ini, (Nurliah Nurdin, 2012: 56).

Sehingga demikian, UUD 1945 sebelum diamandemen sulit bagi kita memberikan gambaran yang utuh tentang sistem pemerintahan yang dianut. Di satu sisi, konstitusi hendak mengatakan bahwa Indonesia menganut sistem pemerintahan presidensial, tetapi di sisi yang lain konstitusi juga memuat 
unsur-unsur sistem pemerintahan parlementer, inilah yang disebut sistem kekeluargaan (perpaduan antara sistem presidensial dan parlementer).

Untuk memahami konsep sistem presidensial setidaknya ada tiga hal dasar sebagai parameternya seperti dijelaskan Lijphart bahwa, terdapat tiga pokok ciri khas sistem presidensial yakni: pertama, presiden atau kepala pemerintahan dipilih untuk masa jabatan yang bersifat tetap (fixed term); kedua, presiden dipilih secara langsung oleh rakyat ataupun melalui dewan pemilih (electoral college) seperti di Amerika Serikat; dan ketiga, presiden adalah pusat kekuasaan dengan mana eksekutif bersifat tunggal, (Arend Lipjhart, 1995: 4-6). Lalu pertanyaannya adalah, bagaimana memvisualisasikan secara tepat letak presiden dalam skema UUD 1945? Sistem pemerintahan apa yang dianut oleh UUD 1945 sebelum diubah? Dan, bagaimana realitas praktik penyelenggaraan negara dalam sistem presidensial tersebut?

Untuk menjawab pertanyaan ini perlu diketahui hal-hal yang berkaitan dengan UUD 1945 dan pengaturan berkaitan dengan Presiden yakni, UUD 1945 terdiri dari Pembukaan, Batang Tubuh (37 Pasal, Aturan Peralihan dan Aturan Tambahan), dan Penjelasan. Kemudian yang berkaitan dengan presiden, dapat dilihat berdasarkan Batang Tubuh UUD 1945 dan Penjelasan, sebagai berikut.

a) Presiden Republik Indonesia memegang kekuasaan pemerintahan menurut UUD (Pasal 4 ayat (1)).

b) Presiden dan Wakil Presiden memegang jabatannya selama masa lima tahun dan sesudahnya dapat dipilih kembali (Pasal 7).

c) Menteri-menteri itu diangkat dan diberhentikan oleh Presiden (Pasal 17 ayat (2)).

d) Presiden dan Wakil Presiden dipilih oleh MPR dengan suara yang terbanyak (Pasal 6 ayat (2)).

e) Kedaulatan adalah ditangan rakyat, dan dilakukan sepenuhnya oleh MPR (Pasal 1 ayat (2))

f) “...Presiden yang diangkat oleh Majelis, bertunduk dan bertanggung jawab kepada Majelis. Ia ialah "mandataris" dari Majelis, ia berwajib menjalankan putusan-putusan Majelis. Presiden tidak "neben," akan tetapi "untergeordnet" kepada Majelis." (Penjelasan Umum Tentang Sistem Pemerintahan Negara, angka III). g) “...Presiden ialah penyelengaraan pemerintah negara yang tertinggi." (Penjelasan Tentang Sistem Pemerintahan Negara, angka IV).

h) "Disampingnya Presiden adalah DPR. Presiden harus mendapat persetujuan DPR untuk membentuk undangundang (Gesetgebung) dan untuk menetapkan APBN (Staatsbegrooting). Oleh karena itu, Presiden harus bekerja bersama-sama dengan Dewan, tetapi Presiden tidak bertanggung jawab kepada Dewan, artinya kedudukan Presiden tidak tergantung dari pada Dewan..." (Penjelasan Tentang Sistem Pemerintahan Negara, angka V), (Lihat: T. Sri Soemantri Mertosuwignyo, 2006: 4-5).

UUD 1945 agaknya hendak menganut sistem presidensial, yang ditandai oleh beberapa hal: (1) Presiden adalah kepala negara sekaligus kepala pemerintahan; (2) Presiden tidak bertanggung jawab kepada DPR dan DPR tidak dapat menjatuhkan Presiden; (3) Presiden dipilih melalui badan pemilihan yaitu MPR, (Indra J. Piliang dan T.A. Legowo, 2006: 84).

Walaupun demikian, sistem ketatanegaraan berdasarkan UUD 1945 juga memunyai ciri-ciri sistem parlementer terlihat di dalamnya:

1. Presiden dipilih oleh MPR dengan suara terbanyak berdasarkan Pasal 6 ayat (2) UUD 1945. Presiden yang terpilih itu diangkat oleh MPR dan sewaktu-waktu MPR dapat meminta pertanggungjawaban presiden, sesuai dengan ketentuan mengenai sistem pemerintahan negara yang diatur dalam Penjelasan umum UUD 1945. Presiden yang terpilih dan diangkat oleh MPR itu tidak "neben" tetapi "untergeodnet" kepada majelis karena dipilih dan diangkat oleh MPR, maka presiden juga dapat diberhentikan oleh MPR.

2. Adanya supremasi parlemen, berdasarkan ketentuan Pasal 1 ayat (2) yang berbunyi: "Kedaulatan adalah di tangan rakyat, dan dilakukan sepenuhnya oleh MPR."

3. Setiap UU yang dibentuk harus mendapat persetujuan DPR sesuai dengan ketentuan Pasal 5 ayat (1), Pasal 20, Pasal 21 ayat (2), Pasal 22, dan Pasal 23 UUD 1945. Hal ini juga dijelaskan di dalam Penjelasan umum UUD 1945. Presiden harus mendapat 
persetujuan DPR untuk membentuk UU dan untuk menetapkan APBN. Karena itu presiden harus bekerja bersama-sama dengan DPR, (Sulardi, 2012: 74-75).

Letak persoalannya adalah, apa yang dimaksud dengan Kepala Negara dalam Konstitusi UUD 1945 (sebelum amandemen)? Tidakkah Presiden sebagai Kepala Negara seyogianya berada pada tempat tertinggi dalam konstitusi, namun UUD 1945 (pasal beserta penjelasan-nya), seakan memposisikan Presiden setara dengan fungsi Perdana Menteri seperti yang biasa berlaku dalam sistem parlementer. Ini disebabkan Presiden bertanggung jawab kepada MPR dan ketika MPR menolak pertanggungjawaban Presiden maka MPR dapat memberhentikan Presiden dari jabatannya. Ketentuan inilah yang mirip dengan parameter dalam sistem pemerintahan parlementer, yakni parlemen dapat menjatuhkan Perdana Menteri. Hal itu terjadi: (1). Ketika Presiden Soekarno diberhentikan dari jabatannya oleh MPRS melalui Ketetapan MPRS Nomor: XXXI/MPRS/1967 tentang Pencabutan Kekuasaan Pemerintahan Negara dari Presiden Soekarno; dan (2). Ketika MPR-RI mengeluarkan Ketetapan MPR-RI Nomor: II/MPR/2001 tentang Pertanggungjawaban Presiden Republik Indonesia K.H. Abdurrahman Wahid. Dalam Pasal 2 ditentukan: "Memberhentikan K.H. Abdurrahman Wahid sebagai Presiden Republik Indonesia dan mencabut serta menyatakan tidak berlaku lagi Ketetapan MPR-RI Nomor: VII/MPR/1999 tentang Pengangkatan Presiden Republik Indonesia," (Lihat: T. Sri Soemantri Mertosuwignyo, 2006: 5; dan Hendarmin Ranadireksa, 2007: 9-10)Dari ketentuanketentuan yang telah dikemukakan dan dari dua peristiwa yang telah disebutkan, Maswadi Rauf berpendapat bahwa sebelum diubah, "Sistem presidensial kita dibawah UUD 1945 yang asli itu sistem presidensialisme dengan rasa parlementer," (Wawancara, Maswadi Rauf, 2015).

Namun dalam praktiknya, tepatnya dalam masa transisi, yaitu dari masa penjajahan ke kemerdekaan, belum semua lembaga negara sebagaimana diamanatkan UUD 1945 terbentuk, sehingga kekuasaan Presiden sangat kuat atau bahkan mutlak. Sebab berdasarkan Pasal IV Aturan Peralihan UUD 1945, untuk sementara fungsi MPR, DPR, dan DPA dijalankan oleh Presiden dengan bantuan sebuah Komite Nasional. Dengan demikian, dalam kurun waktu tiga bulan (Agustus-Oktober 1945), UUD 1945 mendudukkan presiden sebagai diktator atau apa yang kemudian dikenal dengan istilah diktator konstitusional. DPR yang berfungsi mengawasi pekerjaan Presiden dan MPR yang berhak meminta pertanggungjawaban Presiden, semuanya berada dalam kekuasaan Presiden. Sampai pada akhirnya, perkembangan perpolitikan di tanah air menghadirkan dan menetapkan Komite Nasional Indonesia Pusat (KNIP) sebagai pengganti MPR, dan lambatlaun perkembangan ketatanegaraan meski Indonesia tetap menganut UUD 1945 dengan sistem pemerintahan presidensial, tetapi dalam praktik diterapkan sistem parlementer, (Indra J. Piliang dan T.A. Legowo, 2006: 85).

Sistem perpaduan ini ternyata malah menciptakan ketidakstabilan karena Presiden bisa dijatuhkan setiap saat oleh MPR, atas usul DPR, tentu saja ini konsekuensi sistem kekeluargaan yang menunjukkan implikasi dari variasi sistem parlementer.

Dalam rangka pemurnian sistem presidensial melalui Amandemen UUD 1945 dilakukan tiga langkah sebagai berikut. Langkah pertama adalah melakukan perubahan terhadap posisi kekuasaan membuat undang-undang dan pembatasan masa jabatan Presiden. Kekuasaan membuat undang-undang yang semula diberikan kepada Presiden kini diamandemen kepada DPR (Pasal 20 ayat (1)), kendati tetap ada hak Presiden mengajukan rancangan undang-undang kepada DPR, (Pasal 5 ayat (1)). Ketentuan itu merupakan prinsip sistem presidensial, (Wawancara by phone, Sulardi, 2015). Lalu, pembatasan masa jabatan Presiden yang sebelumnya multitafsir, dari yang sebelumnya masa jabatan Presiden selama lima tahun dan sesudahnya dapat dipilih kembali, menjadi maksimal dua periode atau dua kali lima tahun, (Pasal 7).

Langkah kedua yang merupakan usaha pemurnian terhadap sistem presidensial adalah melarang Presiden membekukan dan/atau membubarkan DPR (Pasal 7C), serta memperbaharui tata cara impeachment terhadap presiden (Pasal 7A dan 7B). Sehingga, selain karena tidak lagi memenuhi syarat sebagai Presiden, atau habis masa jabatannya, atau meninggal dunia, presiden harus berhenti dari jabatannya karena telah terbukti melakukan pelanggaran hukum berupa pengkhianatan terhadap negara, korupsi, penyuapan, tindak pidana berat lainnya, atau perbuatan tercela, berdasarkan pertimbangan hukum dari MK yang telah memunyai kekuatan hukum mengikat.

Prosedur impeachment ini menyiratkan bahwa pemberhentian presiden tidak lagi hanya semata persoalan politik, tetapi lebih banyak ke 
persoalan hukum. Pengaturan ini merupakan solusi bagi terlalu mudahnya Presiden di makzulkan oleh DPR yakni dengan mempersulit impeachment presiden. Ini berarti memperkuat sistem presidensial dengan menciptakan keseimbangan antara DPR dan Presiden, atau memperkuat dual legitimation (legitimasi ganda) antara Presiden dan DPR, (Wawancara, Maswadi Rauf, 2015).

Langkah ketiga adalah memperbaharui (eksistensi) MPR. Menurut rumusan baru, kedudukan MPR tidak lebih dari lembaga tinggi negara biasa, bukan lagi lembaga tertinggi negara yang menjalankan kedaulatan rakyat karena kedaulatan tetap berada di tangan rakyat dan dilaksanakan menurut UUD, sehingga terakomodirnya prinsip demokrasi konstitusional (Pasal 1 ayat (2)). Serta, wewenang MPR untuk memilih Presiden dan Wakil Presiden telah ditiadakan dengan memberikan kedaulatan sepenuhnya kepada rakyat untuk memilih Presiden dan Wakil Presiden secara langsung, (lihat; Pasal 6A ayat (1), (2), (3), (4), dan (5)). Tentu saja perubahan itu memberikan legitimasi yang kuat bagi Presiden sebab Presiden itu dipilih secara terpisah dari anggota-anggota DPR, (Wawancara, Maswadi Rauf, 2015).

Dengan demikian, melalui perubahanperubahan tersebut MPR tidak hanya meniadakan unsur-unsur sistem parlementer dalam UUD 1945 melainkan juga sekaligus memperkuat Presidensialisme dengan menegaskan kedaulatan rakyat tanpa melalui MPR, dan sebagai konsekuensi logisnya adalah keharusan pemilihan secara langsung pasangan Presiden dan Wakil Presiden. Dalam kaitan pemurnian Presidensialisme, paling kurang ada tiga langkah yang dilakukan MPR dalam amandemen konstitusi, yaitu: pertama, pengalihan fungsi dan otoritas legislasi dari Presiden ke DPR serta pembatasan masa jabatan Presiden; kedua, penegasan bahwa Presiden tidak dapat membubarkan DPR serta memperbaiki mekanisme pemakzulan terhadap Presiden; dan ketiga, pembaruan posisi MPR yang sebelumnya memiliki supremasi politik serta pemilihan Presiden dan Wakil Presiden secara langsung oleh rakyat, (Wawancara, I Made Leo Wiratma, 2015).

\section{Analisis Antara Rakyat dan Perkembangan Partai Politik}

Hasil amandemen ke-IV tahun 2002, bahwa MPR bukanlah lembaga tertinggi negara lagi, sekarang kedudukannya sederajat dengan lembaga-lembaga lainnya. Mengapa? Karena Presiden dan Wakil Presiden menurut ketentuan
UUD 1945 sekarang dipilih langsung oleh rakyat, sehingga karena itu tidak lagi bertunduk dan bertanggung jawab kepada MPR seperti sebelumnya, (Beddy Iriawadi Maksudi, 2013: 145) hal ini berdampak pula tereduksinya kewenangan MPR, satu kewenangan MPR yang dihapus yakni membuat Garis-Garis Besar Haluan Negara (GBHN), sebagai konsekuensi logisnya Presiden menggunakan visi-misi pada saat kampanye di Pemilihan Umum Presiden (Pilpres), dan dirumuskan dalam bentuk Program Pembangunan Nasional (Propernas), Propernas merupakan rencana pembangunan lima tahun yang ditetapkan bersama antara Presiden dan DPR. Selanjutnya, dirinci dalam Rencana Pembangunan Tahunan (Repeta) yang memuat APBN, sehingga menjadi logis kalau Presiden menjalankan program-programnya, (Wawancara by phone, Sulardi, 2015; dan Majelis, 2008: 14).

Perubahan MPR atas kewenangan dan kekuasaannya merupakan konsekuensi logis atas hasil pemikiran berdasarkan realitas penyelenggaraan negara yang lalu, misal, apa yang diputuskan oleh MPR mengenai keterpilihan seorang Presiden, karena Presiden kala itu masih menjabat sebagai mandataris MPR, malah yang terjadi adalah seringkali tidak sesuai dengan apa yang diinginkan dan diharapkan oleh rakyat yang diwakili, contoh konkrit dari hal ini adalah ketika MPRS mengangkat Soekarno sebagai Presiden seumur hidup, rakyat belum tentu sependapat dengan Majelis. Demikian pula ketika MPR memutuskan untuk terus mengangkat Soeharto menjadi Presiden selama 32 tahun, belum tentu sesuai dengan kehendak rakyat. Terbukti bahwa dalam masa jabatan terakhirnya, Soeharto diturunkan dari kedudukannya sebaga Presiden di tengah masa jabatannya itu oleh kekuatan rakyat (people's power).

Sesuai amanat UUD 1945 (hasil amandemen) dan dikuatkan oleh keputusan Mahkamah Konstitusi (MK) tahun 2013 lalu, makin mengukuhkan bahwa Partai Politik atau gabungan partai politik perserta pemilu yang dapat mencalonkan pasangan calon presiden dan wakil presiden. Problematika ini menunjukkan bahwa bukan rakyat sebagai pemilih yang patut disalahkan ketika terpilihnya "orang-orang bodoh" dalam tampuk kekuasaan, rakyat dalam Pilpres maupun Pemilihan Umum Legislatif (Pileg) sekalipun, telah jelas dan tegas hanya disodorkan calon-calon yang menurut Partai Politik adalah yang terbaik. Partai Politik dianggap struktur perantara utama antara masyarakat dan pemerintah. Partai politik memainkan peran yang penting dalam sistem 
pemerintahan demokrasi, sebab partai memungkinkan warga untuk berpartisipasi secara padu dalam sistem pemerintahan yang memungkinkan terpilihnya sejumlah besar jabatan politik, (parafrasa, Richard S. Katz dan William Crotty, 2014: 7-8).

Permasalahan terbesar dalam Pilpres adalah regulasi dalam undang-undang Pilpres menafikan urgensi pelembagaan proses seleksi kandidat presiden oleh partai politik secara terbuka dan demokratis, bahkan juga cenderung menutup akses dan partisipasi publik, ini menunjukkan bahwa hanya pemilihan umum semata yang merupakan ekspresi dari kehendak rakyat. Malah, undang-undang Pilpres justru memberi "cek kosong" kepada partai politik untuk menentukan calon presiden (capres) dan calon wakil presiden (cawapres) masingmasing, sehingga yang berlangsung kemudian adalah penetapan capres dan mekanisme capres secara oligarkis oleh ketua umum ataupun gabungan pimpinan partai politik. Hampir tidak ada kesempatan bagi publik memilih kandidat berdasarkan kapasitas para capres/cawapres. Lebih buruk lagi, seolah-olah posisi sebagai ketua umum atau pimpinan partai politik merupakan "tiket" untuk menjadi capres, (Syamsuddin Haris, 2014: 153-154).

Meski dapat dianggap kecenderungan ketua umum atau pimpinan partai politik merupakan "tiket" untuk menjadi capres telah mulai sedikit ditinggalkan melalui dicalonkannya Joko Widodo (Jokowi) sebagai capres dalam Pilpres 2014 lalu. Meski demikian, keterpilihan Jokowi untuk dicalonkan sebagai Presiden masih terjadi perdebatan terkait Surat Mandat Pencalonan Jokowi oleh Megawati tertangal 14 Maret 2014, yang menimbulkan kontroversi mengenai Joko Widodo sebagai Petugas Partai untuk menjadi calon presiden. Bahkan, banyak yang menduga bahwa kebijakan yang dibuat oleh Jokowi tidak akan lepas dari pengaruh Megawati sebagai Ketua Umum PDI-Perjuangan. Kondisi yang menegasikan adanya indikasi "balas budi" Jokowi karena penunjukkannya sebagai presiden merupakan hasil dari sikap "mengalah" Megawati untuk tidak "nyapres," sekaligus tidak meneruskan tradisi trah Soekarno yang dicalonkan sebagai RI 1. Sikap "balas budi" ini dikhawatirkan akan menganggu kinerja Jokowi karena ada proses bargaining politics dalam pemilihan posisi-posisi strategis, seperti menteri, kapolri, kejaksaan, dll, (Ari Ganjar Herdiansah, 2015: 6). Meski penafsiran tersebut tidak sepenuhnya benar, sebab realitas dari kepemimpinan Jokowi menunjukkan kepuasaan dari masyarakat terus meningkat dalam rentang tiga tahun kepemimpinannya, berdasarkan temuan Centre for Strategic and International Studies (CSIS) menunjukkan tingkat kepuasan publik pada 2015 terhadap pemerintahan Jokowi-JK 50,6 persen, pada 2016 meningkat menjadi 66,5 persen, dan sesuai dengan survei terakhir sebesar 68,5 persen, (Koran Tempo, 13 September 2017: 12). Ini disebabkan bahwa dalam menjalankan pemerintahannya Presiden Jokowi berupaya mempertemukan di antara berbagai kepentingan dengan menggunakan konsep win-win solution, yang memang menjadi pilihan dari pola Jokowi dalam mengelola wilayah dukungan, misalnya antara kepentingan partai dan kepentingan masyarakat, antara kepentingan pemerintah dengan kepentingan masyarakat, (Elaborasi dari berbagai sumber data: Djayadi Hanan, 2015; Ikhsan Darmawan, 2015; dan Bivitri Susanti, 2016).

\section{KESIMPULAN}

Hasil amandemen UUD 1945 yang telah diuraikan di atas, jelas bahwa disemangati oleh mewujudkan demokrasi konstitusional yang kala itu hasilnya masih jauh dari cukup, dengan dasar bahwa negara diselenggarakan sesuai dengan kehendak rakyat, dan gagasan negara demokrasi yang konstitusional tersebut memang wujud dari penyelengaraan negara yang mengalami dinamika, pada aspek penataan lembaga negara, proses legislasi, maupun judicial review; ini menunjukkan bahwa dinamika tersebut berkelindan dengan semangat perkembangan gagasan, konstelasi kenegaraan, dan semangat menata ulang struktur politik ketatanegaraan yang diwariskan UUD 1945 asli, (Janedjri M. Gaffar, 2012: 15) .

Berdasarkan uraian di atas juga menunjukkan bahwa kepuasan masyarakat terhadap kepemimpinan Jokowi sebagai Presiden sebesar 68,3 persen tersebut, ini yang menjelaskan bahwa pilihan rakyat dalam realitas demokrasi di Indonesia tidaklah menghasilkan orang-orang bodoh ke tampuk kekuasaan dan kondisi rakyat kita bukanlah "pemilih yang bodoh" buktinya rakyat dapat menghindari diri dari terpilihnya orang-orang bodoh dalam tampuk kekuasaan. Serta keberhasilan kepemimpinan Presiden Jokowi tergambarkan dari kepuasan rakyat Indonesia tersebut, ini juga menunjukkan bahwa keterpilihan calon presiden 2014 lalu yang dapat kita anggap memang dapat memenuhi kehendak rakyat melalui kebijakan publik yang diharapkan oleh masyarakat Indonesia sehingga rakyat menyatakan kepuasannya terhadap Presiden Jokowi. Meski dalam pengelolaan pemerintahannya yang menggunakan konsep win-win solution untuk 
mempertemukan di antara berbagai kepentingan, sekaligus konsep ini memang tak bisa dimungkiri bahwa arah Jokowi dalam kepemimpinannya tentu pula harus dilihat bahwa telah terjadinya politik akomodasi dan transaksional dalam memerintah, namun ini juga menunjukkan bahwa Jokowi merupakan pemimpin yang tak naif terhadap dukungan politik dari partai-partai politik sebagai konsekuensi kita menerapkan sistem multipartai, sepertinya hal ini memperoleh permakluman dari masyarakat.

Realitas ini berbeda jika kita bandingkan dengan realitas pemilihan presiden masih menggunakan sistem pemilihan melalui MPR yang malah menghasilkan pemimpin yang tidak didukung penuh oleh rakyatnya dan menghasilkan pemimpin yang otoriter. Realitas masa lalu tersebut, juga menunjukkan bahwa konstitusi kita tidak cukup melembagakan proses seleksi pemimpin secara demokratis, ini juga disebabkan oleh UUD 1945 hanya mengatur prinsip-prinsip ketatanegaraan dan pemerintahan bersifat kuasi presidensial dan yang bersifat umum, (Syamsuddin Haris, 2014: 149).

\section{DAFTAR PUSTAKA}

Bahar, Saafroedin, Kusuma, Ananda B., dan Hudawati, Nannie, Risalah Sidang Badan Penyelidik Usaha-Usaha Persiapan Kemerdekaan Indonesia (BPUPKI), dan Panitia Persiapan Kemerdekaan Indonesia (PPKI). (1995). Jakata: Sekretariat Negara Republik Indonesia.

Gaffar, Janedjri M. (2012). Demokrasi Konstitusional: Praktik Ketatanegaraan Indonesia Setelah UUD 1945.

Faisal, Sanipah. (1990). Penelitian Kualitatif: Dasar-dasar dan Aplikasi, Malang: YA3 Malang.

Hanan, Djayadi. (2014). Menakar Presidensialisme Multipartai Di Indonesia: Upaya Mencari Format Demokrasi yang Stabil dan Dinamis dalam Konteks Indonesia, Bandung: Mizan.

Haris, Syamsuddin. (2014). Partai, Pemilu, dan Parlemen Era Reformasi, Jakarta: Yayasan Obor Indonesia.

Herdiansah, Ari Ganjar. (2015). Paradoks Koalisi Tanpa Syarat Suatu Tinjauan dari Perspektif Sosiologi Politik, Jakarta: Rajawali Pers,.

Herdiansyah, Haris. (2010). Metodologi Penelitian Kualitatif untuk Ilmu-ilmu Sosial, Jakarta: Salemba Humanika.
Katz, Richard S., dan Crotty, William. (2014). Handbook Partai Politik, Bandung: Nusamedia.

Koran Tempo, 12 September 2017.

Kusuma, R.M.A.B. (2005). "Profil Founding Fathers dan Kaitannya dengan Sistem Pemerintahan Indonesia”. Jurnal Konstitusi, 2 (1).

Leo Wiratma, I Made, Purifikasi Sistem Presidensiil, dalam Indra J. Piliang dan T.A. Legowo, ed. (2006). Desain Baru Sistem Politik Indonesia. Jakarta: CSIS.

Lipjhart, Arend. (1995). Sistem Pemerintahan Parlementer dan Presidensial (Parliamentary versus Presidential Government), terjemahan Ibrahim R., at.all, Jakarta: Raja Grafindo Persada.

Majelis, Mempertanyakan Arah Pembangunan Nasional, Edisi No. 10, Tahun II, Februari 2008.

Maksudi, Beddy Iriawan. (2013). Sistem Politik Indonesia, Pemahaman Secara Teoretik dan Empirik, Jakarta: RajaGrafindo Persada.

Nurdin, Nurliah. (2012). Komparasi Sistem Presidensial Indonesia dan Amerika Serikat Rivalitas Kekuasaan Antara Presiden dan Legislatif (2004-2009), Jakarta: MIPI.

Ranadireksa, Hendarmin. (2007). Visi Bernegara: Arsitektur Konstitusi Demokratik, Bandung: Fokus Media.

Rohaniah, Yoyoh. (2015). Pengantar Ilmu Politik: Kajian Mendasar Ilmu Politik, Malang: Intranspublishing.

Soemantri Mertosuwignyo, T. Sri, Kapabilitas Dewan Perwakilan Rakyat dalam Menjalankan Mekanisme "Checks and Balances" dalam Hubungan Antara Eksekutif dan Legislatif, (Makalah disampaikan pada Seminar Arah Pembangunan Hukum Menurut UUD 1945 Hasil Amandemen, diselenggarakan oleh Badan Pembinaan Hukum Nasional Departemen Hukum dan HAM RI, Jakarta 29-31 Mei 2006).

Sulardi. (2012). Menuju Sistem Pemerintahan Presidensiil Murni, Malang: Setara Press.

Wawancara Ikhsan Darmawan, Dosen Ilmu Politik Universitas Indonesia, tanggal 27 Oktober 2015, Jakarta.

Wawancara I Made Leo Wiratma, Ahli Hukum Tata Negara dan Peneliti Forum Masyarakat Peduli Parlemen Indonesia (Formappi), tanggal 21 Desember 2015, Jakarta.

Wawancara Sulardi, Dosen Hukum Tata Negara Universitas Muhammadiyah Malang 
(UMM), tanggal 31 Desember 2015, Jakarta-Malang.

Wawancara Maswadi Rauf, Ketua Tim Ahli Bidang Politik PAH I BP MPR 1999-2002, dan Dosen Ilmu Politik di Universitas
Nasional (Unas), 19 Desember 2015, Jakarta.

Wawancara Susanti, Bivitri, Dosen Hukum Tata Negara di Sekolah Tinggi Hukum Indonesia Jentera, tanggal 8 Januari 2016, Jakarta. 